\title{
Evidence-Based Studies and Perspectives of the Use of Brazilian Green and Red Propolis in Dentistry
}

\author{
${ }^{1}$ School of Dentistry, Centro Universitário FUNVIC - UniFUNVIC, \\ São Paulo, Brazil \\ 2Laboratory of Natural Products and Chemometrics, Programa \\ de Pós-Graduação Stricto sensu em Farmácia, Universidade \\ Anhanguera de São Paulo (UNIAN-SP), São Paulo, São Paulo, Brazil \\ 3 Programa de Pós-Graduação Stricto sensu em Biotecnologia \\ e Inovação em Saúde, Universidade Anhanguera de São Paulo \\ (UNIAN-SP), São Paulo, São Paulo, Brazil \\ 4Programa de Pós-Graduação Stricto sensu em Ensino de Ciências \\ em Saúde, Universidade Anhanguera de São Paulo (UNIAN-SP), \\ São Paulo, São Paulo, Brazil
}

Claudemir de Carvalho ${ }^{1}$ Wesley Henrique Cabral Fernandes ${ }^{1}$ Thays Barreto Freitas Mouttinho ${ }^{1}$

Daniela Martins de Souza ${ }^{1}$ Maria Cristina Marcucci' ${ }^{2,3}$ Paulo Henrique Perlatti D’Alpino ${ }^{3,4}$ Address for correspondence Claudemir de Carvalho, Estrada
Radialista Percy Lacerda 1000, Pindamonhangaba-SP, Brazil, CEP
12412-825, (e-mail: prof.claudemircarvalho.pinda@funvic.edu.br).

\begin{abstract}
Keywords

- green propolis

- red propolis

- antibacterial activity

- natural products

This review analyzes the evidence and perspectives of dental use of the green and red propolis produced in Brazil by Apis mellifera L. Multiple applications of propolis were found considering its antibacterial, antifungal, anti-inflammatory, immunomodulatory, antiviral, and healing properties. Its therapeutic effects are mainly due to the presence of alcohols, aldehydes, aliphatic acids, aliphatic esters, amino acids, aromatic acids, aromatic esters, flavonoids, hydrocarbyl esters, ethers, fatty acids, ketones, terpenes, steroids, and sugars. Propolis has been mainly used in dentistry in the composition of dentifrices and mouthwashes. Studies have also demonstrated promising use against dentin hypersensitivity, root canal treatment, Candida albicans, and other microorganisms. Overall review of the literature presented here demonstrated that both Brazilian green and red propolis are effective for the problems of multiple etiologies that affect the oral cavity in different dental specialties.
\end{abstract}

\section{Introduction}

Propolis defines a dark, complex, and naturally occurring resinous substance that is obtained by bees from varied species of plants and transported into the hive where it is then mixed with beeswax, resulting in an adhesive substance. It has been widely used in folk medicine for centuries by different civilizations. ${ }^{1}$ Due to the enormous Brazilian biodiversity, several kinds of propolis including brown and red, less common, which are classified based on the region of production and collection. ${ }^{2}$ In the biodiversity of the flora in Brazil, 13 types of propolis are found. ${ }^{3}$ Propolis collected in a hive not only contains mostly resins plant balms but also beeswax, essential oils, and pollen grains at lower concentrations. In its composition, it can be also found in organic acids and substantial quantities of minerals and vitamins. ${ }^{4}$ Bees are known to use propolis to protect and strengthen hive from rain and pests such as insects and rodents. In this way, propolis maintains the aseptic conditions and the appropriate temperature of their hive. ${ }^{5}$ The abundance of natural compounds found in the propolis favored it to have antibacterial, antiviral, antifungal, anti-inflammatory, analgesic, and other claims. ${ }^{6}$ Propolis has been used as an active ingredient in various commercial products, including dental products. In this way, propolis is found in different commercial presentations and packing in liquid or powder forms. ${ }^{7}$

In this way, a broad spectrum of biological activities results from the complex and varied chemical composition of propolis. On the other hand, many factors affect the propolis therapeutic and medicinal properties such as the 
extraction methods and the area where the propolis was obtained. ${ }^{8}$ Thus, the chemical composition of the propolis is determined by the pasture plant for the bees. Therefore, by comparing the chemical composition of propolis with the supposed origin plant would be the best way to find the plant from which the propolis was collected. ${ }^{4}$ The determination of the geographic region where the propolis was obtained is extremely important for the quality control and for the standardization of propolis extracts to guarantee its therapeutic effects. ${ }^{1}$ The color of propolis depends on its origin, ranging from dark brown to a greenish tinge and to reddish brown. It has a characteristic odor that also varies from one sample to another. ${ }^{1}$ Several compounds are found in propolis. These compounds have been characterized using different methods that demonstrated that they belong to different classes: alcohols, aldehydes, aliphatic esters, acids (aliphatic, aromatic, fatty, and amino acids), esters (aromatic and hydrocarbyl esters), flavonoids, ethers, ketones, terpenes, and steroids. ${ }^{6}$

In spite of the need of more investigations, currently applications of propolis have evolved from folk and traditional medicine to modern medicine thanks to the results of most recently evidence-based research. ${ }^{9}$ The broad applications of multitarget natural products, chemically rich in bioactive agents, such as propolis, have gained more and more attention of the clinicians due to some new and promising areas of use and the development of innovative propolis-containing products that have emerged recently. ${ }^{10}$ Since contemporary dentistry is an area of medicine, ${ }^{6}$ the use of propolis-based products in the different dental areas has increased as well. Common oral cavity diseases include dental caries, gingivitis, periodontitis, and other diseases of the oral mucosa such as angular cheilitis, oral herpes, oral candidiasis, exfoliative glossitis, prosthetic stomatitis (denture stomatitis), and aphthous ulcer, among others. ${ }^{5}$

Considering the enormous potential of propolis in terms of its varied activities evidenced in the literature, the purpose of this study is to review the literature in which both Brazilian green and red propolis uses in the different dental areas were scientifically demonstrated in evidence-based publications.

\section{Review Method}

Reviewers conducted a systematic search for relevant articles published in the English language between 2000 and 2019 indexed in the following databases: PubMed, ISI web of science, Cochrane Database of Systematic Reviews, CINAHL, Scopus, Science Direct, Conference Proceedings, Oral Health Journal Index, LILACS, and Medline. The keywords were in accordance with the DeCS-Health Sciences Descriptors (http://decs.bvs.br/I/decsweb2019.htm): propolis; dental; dentistry, operative; prosthodontics; preventive dentistry; pediatric dentistry; periodontics; surgery, oral; endodontics; orthodontics. Three reviewers independently assessed the methodological quality of selected studies using standardized critical inclusion criteria, which included local and systematic interventions in in vitro and in vivo studies, using animal models as well as in clinical trials describing the effectiveness of the use of green and red propolis in treating or preventing dental diseases in the different dental specialties.

\section{Brazilian Green Propolis}

The green propolis of Southeastern Brazil is often referred to as "Brazilian Propolis," but there are other types of Brazilian propolis. Five different types of propolis have been identified so far: two of red propolis from Northeast Brazil, one type of Southeast green propolis, and two types of brown propolis from the South. Each type of propolis has a different composition. The differences in color and composition in the propolis from the South and Southeast of Brazil are directly related to the geographical origins and to the predominant local vegetation. ${ }^{11}$

The therapeutic effects of the Brazilian green propolis can attributed to several phenolic compounds found in the plant Baccharis dracunculifolia D.C. (B. dracunculifolia), widely distributed in the plant kingdom in Brazil. One of the main phenolic compounds found in the Brazilian green propolis is flavonoids, but other compounds are also found such as phenolic acids and their esters, phenolic aldehydes, alcohols, and ketones. Flavonoids are phenolic compounds present antimicrobial action inhibiting cell division and growth of bacteria and increasing the membrane permeability by affecting the bacterial cell motility. ${ }^{4}$ Although it is the most studied component of propolis, flavonoids are not only responsible for the pharmacological properties. However, in this type of Brazilian propolis, there are many aromatic acids and few flavonoids. ${ }^{11}$

The Africanized bees of the Southeast region are able to produce propolis from buds of leaves of $B$. dracunculifolia not yet expanded, guaranteeing a product with high concentrations of phenols and Artepillin C (3,5-diprenyl-4-hydroxycinnamic acid), a compound only found in propolis in the Southeast region on Brazil. ${ }^{12}$ In this way, caffeic ferulic, $p$-coumaric acids, kaempferol, kaempferide, and Artepillin C are the main constituents of the Brazilian green propolis. ${ }^{13}$ Artepillin C presents several activities such as antioxidant, antimicrobial, anti-inflammatory, antigenotoxic, antiangiogenic, and anticancer properties. ${ }^{14}$ Other phenolic compounds, such as p-coumaric acid and 3-prenyl-4-hydroxycinnamic acid, are also found in this type of propolis extract. Other phenolic compounds, such as p-coumaric acid and 3-prenyl-4-hydroxycinnamic acid, are also found in this type of propolis extract. Green propolis also has an antiradical action against 1,1-diphenyl-2-picrylhydrazyl radicals. It also exhibits a wide spectrum of action, possibly related to the synergic effects of phenolic type compounds such as ferulic and caffeic acids and p-coumaric acid in the extract. ${ }^{15}$

Many biological properties have been reported for Brazilian green propolis, such as antibacterial activity, ${ }^{16}$ antiinflammatory, ${ }^{17}$ antihypertensive, ${ }^{18}$ antihyperlipidemic, ${ }^{19}$ antioxidant, ${ }^{20}$ and antitumor. ${ }^{21}$ Recently, it has been used as a neuroprotectant in neurodegenerative diseases ${ }^{22}$ and in the prevention of cognitive decline in the elderly. ${ }^{23}$-Table 1 demonstrates that the interest in Brazilian green propolis in dentistry is mainly due to its antimicrobial and antiinflammatory activities. 
Table 1 Uses of green propolis according to dental areas

\begin{tabular}{|c|c|c|c|c|}
\hline Dental area & Experimental aim & Activities and/or results & $\begin{array}{l}\text { Experim. } \\
\text { model }\end{array}$ & Ref. \\
\hline \multirow[t]{6}{*}{$\begin{array}{l}\text { Oral hygiene } \\
\text { and caries } \\
\text { pathogens }\end{array}$} & $\begin{array}{l}\text { Cariogenic bacteria } \\
\text { cytotoxicity }\end{array}$ & $\begin{array}{l}\text { - All presented antimicrobial action against Streptococcus } \\
\text { mutans, S. sanguinis, S. salivarius, and Lactobacillus casei } \\
\text { - Low cytotoxicity in osteoblasts in the three concentrations } \\
\text { of varnishes }\end{array}$ & In vitro & 33 \\
\hline & $\begin{array}{l}\text { Evaluate adherence, } \\
\text { appreciation, and } \\
\text { acceptability of the } \\
\text { mouthwash }\end{array}$ & $\begin{array}{l}\text { Of } 25 \text { patients, } 21 \text { completed the study. Most reported } \\
\text { unpleasant taste, but were satisfied and noted positive changes } \\
\text { in oral health; } \\
\text { - Satisfactory adhesion }(\geq 80 \%)\end{array}$ & $\begin{array}{l}\text { In vivo } \\
\text { Human }\end{array}$ & 34 \\
\hline & $\begin{array}{l}\text { Plaque control and } \\
\text { gingivitis }\end{array}$ & $\begin{array}{l}\text { After } 45 \text { and } 90 \text { days of use, there were significant reductions ( } p \\
<0.5 \text { ) in plaque index and gingival index ( } 24 \text { and } 40 \% \text {, respec- } \\
\text { tively), when compared with control samples; } \\
\text { - There were no significant side effects in the soft and hard } \\
\text { tissues of the mouth }\end{array}$ & $\begin{array}{l}\text { In vivo } \\
\text { Human }\end{array}$ & 35 \\
\hline & $\begin{array}{l}\text { Influence on oral } \\
\text { cavity health }\end{array}$ & $\begin{array}{l}\text { - Efficacy in hygiene preparations in two groups of patients: } \\
\text { (1) without pathological changes at the periodontium } \\
\text { boundaries and (2) in cases of risk of gingivitis caused by } \\
\text { biofilm; } \\
\text { - Effective as a support for the removal of the plaque and to } \\
\text { improve marginal periodontal status }\end{array}$ & $\begin{array}{l}\text { In vivo } \\
\text { Human }\end{array}$ & 36 \\
\hline & $\begin{array}{l}\text { Influence on oral } \\
\text { cavity health }\end{array}$ & $\begin{array}{l}\text { - It efficiently aided the removal of the biofilm and improved } \\
\text { the state of the marginal periodontium; } \\
\text { - Antimicrobial activity against gram-positive bacteria, as } \\
\text { Candida albicans; } \\
\text { - No activity against Escherichia coli was observed, but there } \\
\text { was activity mainly against } S \text {. mutans and } L \text {. casei }\end{array}$ & $\begin{array}{l}\text { In vivo } \\
\text { Human }\end{array}$ & 37 \\
\hline & $\begin{array}{l}\text { Comparative evalu- } \\
\text { ation of extracts of } \\
\text { propolis and Baccha- } \\
\text { ris dracunculifolia on } \\
\text { cariogenic factors of } \\
\text { S. mutans }\end{array}$ & $\begin{array}{l}\text { - Both extracts produced a bacteriostatic effect; } \\
\text { - Similar inhibitory effect against acid production and the } \\
\text { synthesis of insoluble and soluble glucans }\end{array}$ & In vitro & 38 \\
\hline
\end{tabular}

(continued) 
Table 1 (continued)

\begin{tabular}{|c|c|c|c|c|}
\hline Dental area & Experimental aim & Activities and/or results & $\begin{array}{l}\text { Experim. } \\
\text { model }\end{array}$ & Ref. \\
\hline \multirow[t]{12}{*}{ Periodontics } & $\begin{array}{l}\text { Effect on oral epi- } \\
\text { thelial dysplasia }\end{array}$ & $\begin{array}{l}\text { - Important protective role during chemically induced lingual } \\
\text { carcinogenesis in rats }\end{array}$ & $\begin{array}{l}\text { In vivo } \\
\text { Animal }\end{array}$ & 39 \\
\hline & $\begin{array}{l}\text { Efficacy against } \\
\text { HSV-1 infection in } \\
\text { rats }\end{array}$ & $\begin{array}{l}\text { - Showed direct anti-HSV-1 activity and intradermal immune } \\
\text { activity against HSV-1 }\end{array}$ & $\begin{array}{l}\text { In vivo } \\
\text { Animal }\end{array}$ & 40 \\
\hline & $\begin{array}{l}\text { Response in the } \\
\text { lingual mucosa of } \\
\text { hamsters submitted } \\
\text { to experimental } \\
\text { carcinogenesis }\end{array}$ & $\begin{array}{l}\text { - There was no significant difference in the evaluation periods } \\
\text { and the presence of squamous cell carcinoma was observed }\end{array}$ & $\begin{array}{l}\text { In vivo } \\
\text { Animal }\end{array}$ & 41 \\
\hline & $\begin{array}{l}\text { Treatment of } \\
\text { periodontitis }\end{array}$ & $\begin{array}{l}\text { - There was a 95\% regression in gingivitis and suppuration in } \\
\text { all the teeth irrigated with the gel, reduction in the probing } \\
\text { depth of the pockets in all teeth not previously scraped and } \\
\text { root planning; } \\
\text { - The reorganization of the alveolar bone was not observed; } \\
\text { - Increased gingival retraction and reduced mobility were } \\
\text { noted. }\end{array}$ & $\begin{array}{l}\text { In vivo } \\
\text { Human }\end{array}$ & 42 \\
\hline & $\begin{array}{l}\text { Effectiveness against } \\
\text { gingivitis }\end{array}$ & $\begin{array}{l}\text { - After } 21 \text { days without oral hygiene, no significant differ- } \\
\text { ence was found for the measurements of papillary bleeding } \\
\text { scores in the group that used the mouthwash compared } \\
\text { with positive control group }\end{array}$ & $\begin{array}{l}\text { In vivo } \\
\text { Human }\end{array}$ & 43 \\
\hline & $\begin{array}{l}\text { Prevention of oral } \\
\text { mucositis induced } \\
\text { by radiation }\end{array}$ & $\begin{array}{l}\text { - Of } 24 \text { patients, } 20 \text { did not develop mucositis, } 2 \text { developed in } \\
\text { grade } 1 \text {, and } 2 \text { developed in grade } 2 \text {; } \\
\text { - No interruption of food intake and no report of pain; } \\
\text { - Candidiasis was not detected in any patient. }\end{array}$ & $\begin{array}{l}\text { In vivo } \\
\text { Human }\end{array}$ & 44 \\
\hline & $\begin{array}{l}\text { Antimicrobial } \\
\text { activity against oral } \\
\text { pathogens }\end{array}$ & $\begin{array}{l}\text { - Inhibited all } 15 \text { microorganisms tested, showing greater } \\
\text { zone of inhibition for Actinomyces spp.; } \\
\text { - Inhibition of cell adhesion and the formation of insoluble } \\
\text { glucan in water }\end{array}$ & In vitro & 45 \\
\hline & $\begin{array}{l}\text { Antimicrobial } \\
\text { activity against oral } \\
\text { pathogens }\end{array}$ & $\begin{array}{l}\text { - Activity against } 8 \text { strains of tested microorganisms, } \\
\text { similar to propolis, with higher activity against strains of } \\
\text { E. salivarius, S. sanguinis, S. mitis, and C. albicans }\end{array}$ & In vitro & 46 \\
\hline & $\begin{array}{l}\text { Susceptibility of oral } \\
\text { pathogenic bacteria } \\
\text { and fungi }\end{array}$ & $\begin{array}{l}\text { - All } 16 \text { microorganisms tested were susceptible to the } \\
\text { extract; } \\
\text { - None of the isolated fractions tested were more active than } \\
\text { the extract }\end{array}$ & In vitro & 47 \\
\hline & $\begin{array}{l}\text { Effect on mecha- } \\
\text { nisms of adherence } \\
\text { of C. albicans }\end{array}$ & $\begin{array}{l}\text { - Exerted influence on the cellular morphology of } C \text {. albicans } \\
\text { and acted on the formation of the germinative tube; } \\
\text { - It has been shown to alter the cell wall of the microorganism }\end{array}$ & In vitro & 48 \\
\hline & $\begin{array}{l}\text { Oral pathogens } \\
\text { and periodontal } \\
\text { fibroblasts }\end{array}$ & $\begin{array}{l}\text { - Inhibited the growth of S. mutans in low concentrations } \\
\text { inhibited the growth of S. sanguinis or Porphyromonas } \\
\text { gingivalis; but did not inhibit the growth of Aggregatibacter } \\
\text { actinomycetemcomitans, even at the highest concentration; } \\
\text { - Low cytotoxicity to the periodontal tissue up to the highest } \\
\text { concentration }\end{array}$ & In vitro & 49 \\
\hline & $\begin{array}{l}\text { Adhesive mucore- } \\
\text { sponsive system for } \\
\text { the treatment of } \\
\text { lesions caused by } \\
\text { HSV-1 }\end{array}$ & $\begin{array}{l}\text { - Inhibited the virus during the viral infection phase; } \\
\text { - Induced damage to the virion; } \\
\text { - Demonstrated ability to protect cells from viral infection }\end{array}$ & In vitro & 50 \\
\hline
\end{tabular}


Table 1 (continued)

\begin{tabular}{|c|c|c|c|c|}
\hline Dental area & Experimental aim & Activities and/or results & $\begin{array}{l}\text { Experim. } \\
\text { model }\end{array}$ & Ref. \\
\hline \multirow[t]{4}{*}{$\begin{array}{l}\text { Oral and } \\
\text { maxillofacial } \\
\text { surgery }\end{array}$} & $\begin{array}{l}\text { Effect of topi- } \\
\text { cal propolis and } \\
\text { dexamethasone on } \\
\text { the healing of oral } \\
\text { surgical wounds }\end{array}$ & $\begin{array}{l}\text { - It had a greater anti-inflammatory effect and reduced the } \\
\text { healing time of surgical wounds compared with dexametha- } \\
\text { sone in Orabase gel }\end{array}$ & $\begin{array}{l}\text { In vivo } \\
\text { Animal }\end{array}$ & 51 \\
\hline & $\begin{array}{l}\text { Evaluation of oral } \\
\text { microflora after } \\
\text { maintenance } \\
\text { hygiene after minor } \\
\text { oral surgeries }\end{array}$ & $\begin{array}{l}\text { - Affected gram-positive rods and bacilli, and gram-negative } \\
\text { bacilli; } \\
\text { - Deep reduction in the amount of Neisseria spp. and strains } \\
\text { of Bifidobacterium spp.; } \\
\text { - Eliminated } 7 \text { species of microorganisms }\end{array}$ & $\begin{array}{l}\text { In vivo } \\
\text { Human }\end{array}$ & 52 \\
\hline & $\begin{array}{l}\text { Influence on hygiene } \\
\text { and buccal microbi- } \\
\text { ota after mandibular } \\
\text { fractures }\end{array}$ & $\begin{array}{l}\text { - Pathogenic and opportunistic microorganisms were elimi- } \\
\text { nated: in } 16 \text { patients there was a reduction of } 54 \text { strains of } \\
\text { microorganisms to } 48 \text { after using the gel with an ethanolic } \\
\text { extract; } \\
\text { - In the } 15 \text { patients who used gel without the EEP there was } \\
\text { an increase from } 41 \text { to } 57 \text { strains. There was no harmful } \\
\text { influence on physiological microflora }\end{array}$ & $\begin{array}{l}\text { In vivo } \\
\text { Human }\end{array}$ & 53 \\
\hline & $\begin{array}{l}\text { Biological activity } \\
\text { in oral health after } \\
\text { rehabilitation of } \\
\text { implants supported }\end{array}$ & $\begin{array}{l}\text { Acted effectively on the reduction in dental plaque and showed a } \\
\text { local therapeutic effect on the marginal periodontium; } \\
\text { - Bacteria with pathogenic potential, particularly stems En- } \\
\text { terobacteriaceae spp; } \\
\text { - Beneficial influence on the bacterial modification of the oral } \\
\text { cavity; } \\
\text { - Little influence on C. albicans spp. }\end{array}$ & $\begin{array}{l}\text { In vivo } \\
\text { Human }\end{array}$ & 54 \\
\hline \multirow[t]{3}{*}{$\begin{array}{l}\text { Dentistry, } \\
\text { operative }\end{array}$} & $\begin{array}{l}\text { Effect on the } \\
\text { physicomechanical } \\
\text { properties of GIC }\end{array}$ & $\begin{array}{l}\text { - Use of propolis combined with glass ionomer cements is } \\
\text { promising } \\
\text { - Proposed as a resource against caries disease and preven- } \\
\text { tion to secondary caries }\end{array}$ & In vitro & 55 \\
\hline & $\begin{array}{l}\text { Antidemineralizing } \\
\text { and antibacterial } \\
\text { effect against S. mu- } \\
\text { tans dental biofilm }\end{array}$ & $\begin{array}{l}\text { - Antibacterial against S. mutans biofilm; } \\
\text { - Low potential to inhibit the demineralization process }\end{array}$ & In vitro & 56 \\
\hline & $\begin{array}{l}\text { As a cavity } \\
\text { disinfectant }\end{array}$ & $\begin{array}{l}\text { - Action only bacteriostatic against S. mutans and L. acidophilus, } \\
\text { having less efficacy than } 2 \% \text { chlorhexidine solution }\end{array}$ & In vitro & 57 \\
\hline Orthodontics & $\begin{array}{l}\text { Hygiene, gingival } \\
\text { state, and oral } \\
\text { microflora in cases } \\
\text { of cleft palate treat- } \\
\text { ed with fixed ortho- } \\
\text { dontic appliance }\end{array}$ & $\begin{array}{l}\text { - Significant decrease in Plate Orthodontic Index, Gingival } \\
\text { Index, and percentage of Actinomyces spp. and } \\
\text { Capnocytophaga spp. }\end{array}$ & $\begin{array}{l}\text { In vivo } \\
\text { Human }\end{array}$ & 58 \\
\hline
\end{tabular}


Table 1 (continued)

\begin{tabular}{|c|c|c|c|c|}
\hline Dental area & Experimental aim & Activities and/or results & $\begin{array}{l}\text { Experim. } \\
\text { model }\end{array}$ & Ref. \\
\hline \multirow[t]{5}{*}{ Endodontics } & $\begin{array}{l}\text { Pulpal repair after } \\
\text { pulpotomy }\end{array}$ & $\begin{array}{l}\text { - Inflammatory response consisting of neutrophils was ob- } \\
\text { served; necrosis was observed, and its extension increased } \\
\text { with time; } \\
\text { - Vascular congestion, edema and hemorrhage were } \\
\text { observed }\end{array}$ & $\begin{array}{l}\text { In vivo } \\
\text { Animal }\end{array}$ & 59 \\
\hline & $\begin{array}{l}\text { Inflammatory } \\
\text { response of three } \\
\text { cell lines }\end{array}$ & $\begin{array}{l}\text { - Suppresses the LPS-induced inflammatory response of cells } \\
\text { within the root canals }\end{array}$ & In vitro & 60 \\
\hline & $\begin{array}{l}\text { Development of } \\
\text { a propolis-based } \\
\text { irrigant solution } \\
\text { and its effect on the } \\
\text { bonding of fiber- } \\
\text { glass posts to the } \\
\text { root canal dentin }\end{array}$ & $\begin{array}{l}\text { - Propolis-based irrigation protocols do not interfere in the } \\
\text { bonding performance of posts cemented to root canal } \\
\text { dentin }\end{array}$ & In vitro & 61 \\
\hline & $\begin{array}{l}\text { Decontamination } \\
\text { ability when asso- } \\
\text { ciated with calcium } \\
\text { hydroxide paste }\end{array}$ & $\begin{array}{l}\text { - Associated with calcium hydroxide paste as vehicle and } \\
\text { addictive } \\
\text { - Increased the antimicrobial effect of the calcium hydroxide } \\
\text { paste }\end{array}$ & In vitro & 62 \\
\hline & $\begin{array}{l}\text { Proliferation and } \\
\text { apoptosis of peri- } \\
\text { odontal ligament } \\
\text { fibroblasts }\end{array}$ & $\begin{array}{l}\text { - Decreased apoptosis and increased metabolic activity and } \\
\text { proliferation of periodontal ligament cells }\end{array}$ & In vitro & 63 \\
\hline \multirow[t]{3}{*}{$\begin{array}{l}\text { Prosthodon- } \\
\text { tics }\end{array}$} & $\begin{array}{l}\text { Treatment of oral } \\
\text { candidiasis }\end{array}$ & $\begin{array}{l}\text { - All patients treated with the extract had lesion regression } \\
\text { similar to that observed in patients treated with nystatin }\end{array}$ & $\begin{array}{l}\text { In vivo } \\
\text { Human }\end{array}$ & 64 \\
\hline & $\begin{array}{l}\text { Efficacy for the } \\
\text { treatment of pros- } \\
\text { thetic stomatitis }\end{array}$ & $\begin{array}{l}\text { - All patients treated with the gel had complete clinical remis- } \\
\text { sion of edema and palmar erythema, which also occurred in } \\
\text { the positive control }\end{array}$ & $\begin{array}{l}\text { In vivo } \\
\text { Human }\end{array}$ & 65 \\
\hline & $\begin{array}{l}\text { Comparison with } \\
\text { miconazole gel in } \\
\text { the treatment of } C \text {. } \\
\text { albicans associated } \\
\text { with prosthetic } \\
\text { stomatitis }\end{array}$ & $\begin{array}{l}\text { - Significant reduction or complete remission of prosthetic } \\
\text { stomatitis and significant decrease of } C \text {. albicans colonies; } \\
\text { - Effect similar to that of miconazole gel }\end{array}$ & $\begin{array}{l}\text { In vivo } \\
\text { Human }\end{array}$ & 66 \\
\hline
\end{tabular}

Abbreviations: EEP, ethanolic extract of propolis; GIC, glass ionomer cement; HSV-1, herpes simplex virus type 1; LPS, lipopolysaccharide; SEM, scanning electron microscope. 


\section{Brazilian Red Propolis}

Brazilian red propolis is obtained by bees from the species Apis mellifera mainly from the sap of Dalbergia ecastophyllum, which is a leguminous plant found in the northeastern mangroves of Brazil. ${ }^{12}$ One of its botanical origin is a legume identified as D. ecastophyllum L., found in a region of tropical coastal climate, specifically the mangrove region. Its stem is reddish, so the product of propolis accompanies the coloration. ${ }^{4}$ Red propolis presents an intense red color and other characteristics that makes it different from other types of propolis found in Brazil ${ }^{24}$ and throughout the world. ${ }^{3}$ The main secondary metabolites present in the red propolis are isoflavonoids, propolones/guttiferones, terpenes, chalcones, and phenolic compounds. ${ }^{25}$ It also has chemical substances such as vestitol, neovestitol, C-glycoside, liquiritigenin, isoliquiritigenin, formononetin, and medicarpin that are not found in other types of propolis. ${ }^{26}$ Compounds such as daidzein, biochanin $A,{ }^{27}$ pinocembrin, and quercetin ${ }^{24}$ are considered biomarkers of Brazilian red propolis. Brazilian red propolis presents antimicrobial, anti-inflammatory and immunomodulatory, antioxidant, and antiproliferative activities due to a distinctive chemical composition, mainly isoflavone that is important against numerous diseases. ${ }^{28}$ Other actions of ethanolic extracts of red propolis such as antioxidant, antimicrobial, antipyretic, and cytotoxic properties of Brazilian red propolis were also found. ${ }^{29}$ Only red propolis extract was able to inhibit the growth of tumor cells. In addition, red propolis showed the highest anti-Trypanosoma cruzi $\mathrm{Y}$ activity and a potential therapeutic action against Chagas disease, ${ }^{29}$ both of which are endemic diseases in Brazil and Latin America. Red propolis extracts was also found to be able to inhibit gram-positive bacteria, and other kinds of cancer. These findings demonstrated a strong biological activity of red propolis extracts, possibly favoring a wider use in different application forms.

- Table 2 shows the interest in Brazilian red propolis in dentistry. - Table 3 shows the synergistic use of both green and red propolis.

\section{Discussion}

As previously exposed, it is a fact that with the development of modern methods of phytochemical analysis associated with different methods to extract a variety of bioactive agents, deeper knowledge of propolis properties has allowed an increase in its general use considering its antibacterial, antiviral, antifungal, anti-inflammatory, antioxidant, and chemopreventive actions. Overall action of the chemical compounds found in the different categories of propolis is still being investigated, which will certainly allow the development of new products for healthcare. ${ }^{5}$ In this way, the benefits of propolis have been widely explored by the nutraceutical and pharmaceutical industry with a view to application in the different areas of medicine in the prevention and treatment of oral and systemic disorders. ${ }^{28}$ The use of natural products may significantly reduce the use of conventional treatments and antibiotics, shifting toward the usage of propolis in the management of oral cavity conditions. ${ }^{5}$ Thanks to the multiple bioactive components found in extracts of propolis, it seems to play a synergic role in terms of therapeutic action that is comparatively greater than that when using a drug alone. ${ }^{9}$ In this way, a trend exists in which therapeutic modes using "multi-drugs and multi-targets" are associated. ${ }^{9}$

In spite of the evolving technology in terms of phytochemical properties, factors such as limited investment and incomplete or inconsistent information from preclinical and clinical testing impact the production of derivatives of natural products in the healthcare industry. ${ }^{30}$ Although a vast literature evaluating the biological effects propolis in in vitro and in vivo studies exists, only a small part of them reaches the clinical phase and becomes commercially available. In addition, a lack of clinical trials is also observed in the dental area. ${ }^{3}$ Thus, it is imperative for the development of more clinical trials to explore the benefits of propolis. Thus, it is imperative that more clinical studies need to be performed to explore the benefits of propolis. In this way, in vivo studies are also important for refining the dosages and formulations focused on drug development. ${ }^{31}$

Other issues seem to affect the use of propolis for healthcare. For instance, the time at which propolis and its botanical sources are collected interfere in the composition of propolis, thus resulting in variations in its antibacterial activity. ${ }^{32}$ Another important issue to consider is the predisposition to allergies when consuming products derived from bees, especially toward pollen and honey, as well as by individuals with atopy or asthma. ${ }^{5}$ Other issues include the need of an appropriate processing and dose regulation, to improving the drug efficacy and reducing the drug toxicity. ${ }^{9}$ Although these issues, there is a promising research area aiming to deepen the knowledge in the following areas such as drug-like activity, physicochemical and biochemical properties, pharmacokinetic, and also toxicological characteristics of natural products. The benefits are numerous advantages over other forms of medicine discovery of lead compounds and drug candidates, favoring the development of new drugs, thereby resulting in many benefits, such as significant cost reductions.

Among the several pharmacological properties of propolis, the main purpose of its use in the different dental specialties seems to be mainly related to its antimicrobial (bacteriostatic and bactericidal) actions, identified against different species of gram-positive bacteria. ${ }^{14}$ In this way, according to the findings in the present study, the main application of green and red propolis in the dental specialties is as antimicrobial agent. Oral and maxillofacial surgery (in postoperative control of infections), periodontics (also controlling postoperative infections after gum surgery), endodontics (as a root canal irrigant), oral hygiene (against caries pathogens, hindering S. mutans biofilms), and orthodontics (minimizing enamel demineralization) were the dental specialties that stood out regarding the use of propolis. To a lesser extent, propolis can be also used due to its antioxidant activities and also as an 
Table 2 Uses of red propolis according to dental areas

\begin{tabular}{|c|c|c|c|c|}
\hline Dental area & Experimental aim & Activities and/or results & $\begin{array}{l}\text { Experim. } \\
\text { Model }\end{array}$ & Ref. \\
\hline \multirow[t]{3}{*}{$\begin{array}{l}\text { Oral hygiene and } \\
\text { caries pathogens }\end{array}$} & $\begin{array}{l}\text { In vitro biofilm accu- } \\
\text { mulation and in vivo } \\
\text { caries development }\end{array}$ & $\begin{array}{l}\text { - It hindered the accumulation of Streptococcus mutans biofilms; } \\
\text { - As effective as fluoride (positive control) in reducing the devel- } \\
\text { opment of caries. }\end{array}$ & $\begin{array}{l}\text { In vitro/In } \\
\text { vivo } \\
\text { Animal }\end{array}$ & 26 \\
\hline & $\begin{array}{l}\text { Antimicrobial and } \\
\text { anti-inflammatory } \\
\text { evaluation }\end{array}$ & $\begin{array}{l}\text { - Consistent bioactive compounds that exhibit anti-inflammatory } \\
\text { and antimicrobial activities that can act strongly at low dose } \\
\text { and concentration. }\end{array}$ & In vitro & 67 \\
\hline & $\begin{array}{l}\text { Antimicrobial } \\
\text { activity against car- } \\
\text { iogenic bacteria }\end{array}$ & $\begin{array}{l}\text { 3\% RP reduced S. mutans colonization, decreased concentration } \\
\text { of extracellular polysaccharides and reduced dental enamel } \\
\text { demineralization }\end{array}$ & In vitro & 68 \\
\hline \multirow[t]{9}{*}{ Periodontics } & $\begin{array}{l}\text { Fungicidal action } \\
\text { against Candida spp. }\end{array}$ & $\begin{array}{l}\text { - Isoflavone formononetin acts as a fungicide against Candida } \\
\text { spp. }\end{array}$ & In vitro & 69 \\
\hline & $\begin{array}{l}\text { Anti-inflammatory } \\
\text { action }\end{array}$ & $\begin{array}{l}\text { - It attenuates the inflammatory cascade induced by LPS in mac- } \\
\text { rophages and decreases the formation of chemical mediators } \\
\text { related to inflammation }\end{array}$ & In vitro & 70 \\
\hline & $\begin{array}{l}\text { Antifungal activity } \\
\text { against Candida spp. } \\
\text { isolated from pa- } \\
\text { tients with chronic } \\
\text { periodontitis }\end{array}$ & $\begin{array}{l}\text { - Good fungistatic and fungicidal action against most samples } \\
\text { of Candida species }\end{array}$ & In vitro & 71 \\
\hline & $\begin{array}{l}\text { Antifungal action in } \\
\text { Candida spp. oral }\end{array}$ & $\begin{array}{l}\text { - The lower concentration of the extract had greater antifungal } \\
\text { action }\end{array}$ & In vitro & 72 \\
\hline & $\begin{array}{l}\text { Antifungal activity } \\
\text { and synergism of } \\
\text { propolis with the } \\
\text { use of antifungals } \\
\text { on Candida spp. }\end{array}$ & $\begin{array}{l}\text { - There was synergism with fluconazole: a therapeutic strategy } \\
\text { for the treatment of Candida spp. resistant }\end{array}$ & In vitro & 73 \\
\hline & $\begin{array}{l}\text { Antifungal } \\
\text { potential of Brazilian } \\
\text { red propolis against } \\
\text { Candida spp }\end{array}$ & $\begin{array}{l}\text { Presented strong anti-Candida activity: should be considered to } \\
\text { treat oral and systemic candidiasis }\end{array}$ & In vitro & 74 \\
\hline & $\begin{array}{l}\text { Inhibition of the } \\
\text { growth of oral squa- } \\
\text { mous cell carcinoma } \\
\text { induced }\end{array}$ & $\begin{array}{l}\text { - Preventive chemopreventive activity on the progression of } \\
\text { induced epithelial dysplasia in an experimental model of lip } \\
\text { carcinogenesis }\end{array}$ & $\begin{array}{l}\text { In vivo } \\
\text { Animal }\end{array}$ & 75 \\
\hline & $\begin{array}{l}\text { Antimicrobial } \\
\text { effects on multispe- } \\
\text { cies biofilms }\end{array}$ & $\begin{array}{l}\text { - Decreased biofilm metabolic activity by } 45 \% \text {, with no signifi- } \\
\text { cant difference from chlorhexidine-treated samples }\end{array}$ & In vitro & 76 \\
\hline & Biological activity & $\begin{array}{l}\text { - antimicrobial action against S. aureus and S. mutans and against } \\
\text { tumor cells; } \\
\text { - Fractions were more active than the EEP: nonsynergistic ef- } \\
\text { fect among the various compounds, suggesting isolation and } \\
\text { identification of the various compounds responsible for antiox- } \\
\text { idant, antimicrobial and anticancer activities }\end{array}$ & In vitro & 77 \\
\hline \multirow[t]{2}{*}{$\begin{array}{l}\text { Dentistry, } \\
\text { operative }\end{array}$} & $\begin{array}{l}\text { Desensitization of } \\
\text { the dentinal tubules }\end{array}$ & - Demonstrated occlusion action on the dentinal tubules. & In vitro & 78 \\
\hline & Cavity cleanser & $\begin{array}{l}\text { - Demonstrated no influence in the aesthetics or on the bond } \\
\text { strength of the dentin/resin interface }\end{array}$ & In vitro & 3 \\
\hline
\end{tabular}

Abbreviations: EEP, ethanolic extract of propolis; LPS, lipopolysaccharide. 
Table 3 Associated use of red and green propolis according to dental areas

\begin{tabular}{|c|c|c|c|c|}
\hline Dentistry area & Experimental aim & Activities and/or results & $\begin{array}{l}\text { Experim. } \\
\text { Model }\end{array}$ & Ref. \\
\hline \multirow[t]{2}{*}{$\begin{array}{l}\text { Oral hygiene and } \\
\text { caries pathogens }\end{array}$} & $\begin{array}{l}\text { Synergistic effect on } \\
\text { Streptococcus mutans } \\
\text { and S. sanguinis }\end{array}$ & $\begin{array}{l}\text { All extracts inhibit the growth of both } \\
\text { microorganisms; } \\
\text { - The isolated red propolis extract or associated } \\
\text { with green were more effective than other }\end{array}$ & In vitro & 79 \\
\hline & $\begin{array}{l}\text { Antimicrobial activity } \\
\text { against cariogenic } \\
\text { bacteria }\end{array}$ & $\begin{array}{l}\text { - } 3 \% \text { red propolis reduced S. mutans coloniza- } \\
\text { tion, decreased concentration of extracellular } \\
\text { polysaccharides and reduced dental enamel } \\
\text { demineralization }\end{array}$ & In vitro & 68 \\
\hline
\end{tabular}

anti-inflammatory agent. Propolis was also proven to be useful as part of a novel targeted therapy for some types of cancer in some studies. The main uses of propolis are in the form of extracts or powders, mostly associated with other vehicles or additives in healthcare products. Propolis can also be taken orally in the form of tablets, liquid extracts, and capsule form, or can be used as a mouthwash or local application to areas of affected mucosa.

Overall review of the literature presented here demonstrated that both Brazilian green and red propolis are effective for the problems of multiple etiologies that affect the oral cavity in the different dental specialties. The in vitro and in vivo studies also demonstrated that the green and red propolis could be associated with conventional treatments of the diseases in the oral cavity, possibly reducing the dosage and consequently the side effects of drugs, such as antibiotics and anti-inflammatory medicaments. ${ }^{5}$ In this way, there should be a plea for the development of multidisciplinary collaborative research with a view for innovative ideas, to deepen the knowledge of the synergism of natural products and of the traditional medicine to obtain new drugs and effective treatments. ${ }^{9}$

\section{Conclusions}

Research with natural products has increased in the dental area in the recent years, searching for new healthcare products with lower toxicity, greater biocompatibility, and improved pharmacological activities, associated with more affordable costs to the population. Herbal medicine is widely and popularly accepted with excellent acceptance by the dental clinicians and patients. In this way, a lot of natural products have been developed and marketed by the dental industries supported by specific laboratory and clinical studies and after improving the quality control. Although the literature evidences a significant number of studies using green propolis, the evaluation of Brazilian red propolis by researchers has increased, demonstrating to be a substance of great value in the different areas of dentistry. Natural products and traditional medicines present incomparable advantages due to their unique diversity in terms of chemical structures and biological activities, which allow them to be used to develop new drugs. On the other hand, some issues described in this literature review still need to be solved but with promising results, considering that some of them still need clinical evaluations. In this way, propolis remains as an interesting research area considering its application in biomedical and dentistry areas.

\section{Conflict of Interest}

None declared.

\section{References}

1 Marcucci M, Propolis C. Chemical composition, biological properties and therapeutic activity. Apidologie (Celle) 1995;26:83-99

2 Sawaya ACHF, Souza KS, Marcucci MC, Cunha IBS, Shimizu MT. Analysis of the composition of Brazilian propolis extracts by chromatography and evaluation of their in vitro activity against gram-positive bacteria. Braz J Microbiol 2004;35: 104-109

3 Celerino de Moraes Porto IC, Chaves Cardoso de Almeida D, Vasconcelos Calheiros de Oliveira Costa G, et al. Mechanical and aesthetics compatibility of Brazilian red propolis micellar nanocomposite as a cavity cleaning agent. BMC Complement Altern Med 2018;18(1):219

4 Santos VR, Propolis: Alternative Medicine for the Treatment of Oral Microbial Diseases. In: Sakagami H, ed. Alternative Medicine: IntechOpen; 2012 133-169

5 Šabanović M, Saltović S, Mujkić AA, Jašić M, Bahić Z. Impact of propolis on the oral health. Balk J Dent Med 2019;23:1-9

6 Więckiewicz W, Miernik M, Więckiewicz M, Morawiec T. Does propolis help to maintain oral health? Evid Based Complement Alternat Med 2013;2013:351062-62

7 Abbasi AJ, Mohammadi F, Bayat M, et al. Applications of propolis in dentistry: a review. Ethiop J Health Sci 2018;28(4):505-512

8 Sawaya AC, Barbosa da Silva Cunha I, Marcucci MC. Analytical methods applied to diverse types of Brazilian propolis. Chem Cent J 2011;5(1):27

9 Yuan H, Ma Q, Ye L, Piao G. The traditional medicine and modern medicine from natural products. Molecules 2016;21(5):559

10 Bankova V, Popova M, Trusheva B. New emerging fields of application of propolis. Maced J Chem Chem Eng 2016;35:1-11

11 Marcucci MC, Sawaya ACHF, Custódio AR, Paulino N, Eberlin MN, HPLC and ESI-MS typification: New approaches for natural therapy with Brazilian propolis. Scientific evidence of the use of propolis in ethnomedicine. In: Orsolic N, ed. Scientific Evidence of the Use of Propolis in Ethnomedicine. Kerala, India: Transworld Research Network: 2008 33-54

12 Wang CC, Wang YX, Yu NQ et al. Brazilian green propolis extract synergizes with protoporphyrin IX-mediated photodynamic therapy via enhancement of intracellular accumulation of protoporphyrin IX and attenuation of NF-kappaB and COX-2. Molecules 2017;22(5):22 
13 Szliszka E, Kucharska AZ, Sokół-Łętowska A, Mertas A, Czuba ZP, Król W. Chemical composition and anti-inflammatory effect of ethanolic extract of Brazilian green propolis on activated J774A.1 macrophages. Evid Based Complement Alternat Med 2013;2013:976415

14 Veiga RS, De Mendonça S, Mendes PB, et al. Artepillin C and phenolic compounds responsible for antimicrobial and antioxidant activity of green propolis and Baccharis dracunculifolia DC. J Appl Microbiol 2017;122(4):911-920

15 Popova M, Silici S, Kaftanoglu O, Bankova V. Antibacterial activity of Turkish propolis and its qualitative and quantitative chemical composition. Phytomedicine 2005;12(3):221-228

16 Bankova V, Marcucci MC, Simova S, Nikolova N, Kujumgiev A, Popov S. Antibacterial diterpenic acids from Brazilian propolis. Z Naturforsch C 1996;51(5-6):277-280

17 Paulino N, Teixeira C, Martins R, et al. Evaluation of the analgesic and anti-inflammatory effects of a Brazilian green propolis. Planta Med 2006;72(10):899-906

18 Maruyama H, Sumitou Y, Sakamoto T, Araki Y, Hara H. Antihypertensive effects of flavonoids isolated from Brazilian green propolis in spontaneously hypertensive rats. Biol Pharm Bull 2009;32(7):1244-1250

19 Koya-Miyata S, Arai N, Mizote A, et al. Propolis prevents diet-induced hyperlipidemia and mitigates weight gain in diet-induced obesity in mice. Biol Pharm Bull 2009;32(12):2022-2028

20 Ferreira JM, Fernandes-Silva CC, Salatino A, Negri G, Message D. New propolis type from north-east Brazil: chemical composition, antioxidant activity and botanical origin. J Sci Food Agric 2017;97(11):3552-3558

21 Bhargava P, Grover A, Nigam N, et al. Anticancer activity of the supercritical extract of Brazilian green propolis and its active component, artepillin C: bioinformatics and experimental analyses of its mechanisms of action. Int J Oncol 2018;52(3):925-932

$22 \mathrm{Ni} \mathrm{J}, \mathrm{Wu} \mathrm{Z}$, Meng J, et al. The neuroprotective effects of Brazilian green propolis on neurodegenerative damage in human neuronal SH-SY5Y Cells. Oxid Med Cell Longev 2017;2017:7984327

23 Zhu A, Wu Z, Zhong X, et al. Brazilian green propolis prevents cognitive decline into mild cognitive impairment in elderly people living at high altitude. J Alzheimers Dis 2018;63(2):551-560

24 Daugsch A, Moraes CS, Fort P, Park YK. Brazilian red propolis-chemical composition and botanical origin. Evid Based Complement Alternat Med 2008;5(4):435-441

25 Rufatto LC, Luchtenberg P, Garcia C, et al. Brazilian red propolis: chemical composition and antibacterial activity determined using bioguided fractionation. Microbiol Res 2018;214:74-82

26 Bueno-Silva B, Koo H, Falsetta ML. Alencar SM, Ikegaki M, Rosalen PL. Effect of neovestitol-vestitol containing Brazilian red propolis on accumulation of biofilm in vitro and development of dental caries in vivo. Biofouling 2013;29(10):1233-1242

27 López BG, Schmidt EM, Eberlin MN, Sawaya AC. Phytochemical markers of different types of red propolis. Food Chem 2014; 146:174-180

28 Freires IA, de Alencar SM, Rosalen PL. A pharmacological perspective on the use of Brazilian Red Propolis and its isolated compounds against human diseases. Eur J Med Chem 2016;110:267-279

29 Dantas Silva RP, Machado BA, Barreto GA, et al. Antioxidant, antimicrobial, antiparasitic, and cytotoxic properties of various Brazilian propolis extracts. PLoS One 2017;12(3):e0172585

30 Freires IA, Rosalen PL. How natural product research has contributed to oral care product development? A critical view. Pharm Res 2016;33(6):1311-1317

31 Berretta AA, Arruda C, Miguel FG, et al. Functional properties of Brazilian propolis: from chemical composition until the market. In: Waisundara V, Shiomi N, eds. Superfood and
Functional Food - An Overview of Their Processing and Utilization. London, UK: IntechOpen Limited; 2017 55-98

32 Bueno-Silva B, Marsola A, Ikegaki M. Alencar SM, Rosalen PL. The effect of seasons on Brazilian red propolis and its botanical source: chemical composition and antibacterial activity. Nat Prod Res 2017;31(11):1318-1324

33 De Luca MP, Franca JR, Macedo FA, et al. Propolis varnish: antimicrobial properties against cariogenic bacteria, cytotoxicity, and sustained-release profile. BioMed Res Int 2014;2014:348647

34 Maria E, Morsani Mordente C, Freitas Silva F, et al. Phase II study with mounthrinse containing $5 \%$ of propolis for threemonths: compliance, appreciation and acceptability of the product introduction. R Periodontia 2010;20:53-59

35 Pereira EM, da Silva JL, Silva FF, et al. Clinical evidence of the efficacy of a mouthwash containing propolis for the control of plaque and gingivitis: a phase II study. Evid Based Complement Alternat Med 2011;2011:750249

36 Tanasiewicz M, Skucha-Nowak M, Dawiec M, Król W, Skaba D, Twardawa $\mathrm{H}$. Influence of hygienic preparations with a $3 \%$ content of ethanol extract of Brazilian propolis on the state of the oral cavity. Adv Clin Exp Med 2012;21(1):81-92

37 Skaba D, Morawiec T, Tanasiewicz M, et al. Influence of the toothpaste with Brazilian ethanol extract propolis on the oral cavity health. Evid Based Complement Alternat Med 2013;2013:215391

38 Leitão DP, Filho AA, Polizello AC, Bastos JK, Spadaro AC. Comparative evaluation of in-vitro effects of Brazilian green propolis and Baccharis dracunculifolia extracts on cariogenic factors of Streptococcus mutans. Biol Pharm Bull 2004;27(11):1834-1839

39 Cavalcante DR, Oliveira PS, Góis SM, et al. Effect of green propolis on oral epithelial dysplasia in rats. Rev Bras Otorrinolaringol (Engl Ed) 2011;77(3):278-284

40 Shimizu T, Takeshita Y, Takamori Y, et al. Efficacy of Brazilian propolis against herpes simplex virus type 1 infection in mice and their modes of antiherpetic efficacies. Evid Based Complement Alternat Med 2011;2011:976196

41 Ricardo LR, Ribeiro BP, Soares SA, Lages LN, Oliveira FF, Dornela VF. Effects of propolis on lingual mucosa response of hamsters submitted to experimental carcinogenesis. J Chin Integr Med 2012;10(12):1443-1450

42 do Amaral RC, Tomaz Gomes R, Rocha WMS, Abreu SLR, Santos VR. Periodontitis treatment with Brazilian green propolis gel. Pharmacologyonline 2006;3:336-341

43 Bretz WA, Paulino N, Nör JE, Moreira A. The effectiveness of propolis on gingivitis: a randomized controlled trial. J Altern Complement Med 2014;20(12):943-948

44 Noronha VR, Araujo GS, Gomes RT, et al. Mucoadhesive propolis gel for prevention of radiation-induced oral mucositis. Curr Clin Pharmacol 2014;9(4):359-364

45 Koo H, Gomes BP, Rosalen PL, Ambrosano GM, Park YK, Cury JA. In vitro antimicrobial activity of propolis and Arnica montana against oral pathogens. Arch Oral Biol 2000;45(2):141-148

46 Bruschi ML, Lara EH, Martins $\mathrm{CH}$, et al. Preparation and antimicrobial activity of gelatin microparticles containing propolis against oral pathogens. Drug Dev Ind Pharm 2006;32(2):229-238

47 de Paula A, Tomaz Gomes R, Kwasnicka Santiago W, Souza Dias R, Esperanza Cortés M, Santos V. Susceptibility of oral pathogenic bacteria and fungi to Brazilian green propolis extract. Pharmacologyonline 2006;3:467-473

48 Marinho A, Tomaz Gomes R, Resende Lara S, et al. The effect of Brazilian propolis on the germ tube formation and cell wall of. Candida albicans. Pharmacologyonline 2006;3:352-358

49 Oda H, Nakagawa T, Maruyama K, Dono Y, Katsuragi H, Sato S. Effect of Brazilian green propolis on oral pathogens and human periodontal fibroblasts. J Oral Biosci 2016;58:50-54 
50 Mazia RS, de Araújo Pereira RR, de Francisco LM, et al. Formulation and evaluation of a mucoadhesive thermoresponsive system containing Brazilian green propolis for the treatment of lesions caused by herpes simplex type I. J Pharm Sci 2016;105(1):113-121

51 Lopes-Rocha R, Miranda JL, Lima NL, et al. Effect of topical propolis and dexamethasone on the healing of oral surgical wounds. WHSA 2012;5:25-30

52 Morawiec T, Mertas A, Wojtyczka RD, et al. The assessment of oral microflora exposed to 3\% ethanolic extract of Brazilian green propolis preparation used for hygiene maintenance following minor oral surgeries. BioMed Res Int 2015;2015:869575

53 Niedzielska I, Puszczewicz Z, Mertas A, et al. The influence of ethanolic extract of Brazilian green propolis gel on hygiene and oral microbiota in patients after mandible fractures. BioMed Res Int 2016;2016:9190814

54 Morawiec T, Dziedzic A, Niedzielska I, et al. The biological activity of propolis-containing toothpaste on oral health environment in patients who underwent implant-supported prosthodontic rehabilitation. Evid Based Complement Alternat Med 2013;2013:704947

55 Troca VB, Fernandes KB, Terrile AE, Marcucci MC, Andrade FB, Wang L. Effect of green propolis addition to physical mechanical properties of glass ionomer cements. J Appl Oral Sci 2011;19(2):100-105

56 Cardoso JG, Iorio NL, Rodrigues LF, et al. Influence of a Brazilian wild green propolis on the enamel mineral loss and Streptococcus mutans' count in dental biofilm. Arch Oral Biol 2016;65:77-81

57 Mahabala KY, Shrikrishna SB, Natarajan S, Nayak AP. Ethanolic extracts of Aloe vera and propolis as cavity disinfectants: an in vitro study. Dent Hypotheses 2016;7:61-66

58 Machorowska-Pieniążek A, Morawiec T, Mertas A, Tanasiewicz M, Dziedzic A, Król W. Influence of propolis on hygiene, gingival condition, and oral microflora in patients with cleft lip and palate treated with fixed orthodontic appliances. Evid Based Complement Alternat Med 2013;2013:183915

59 Lima RVE, Esmeraldo MR, de Carvalho MG, et al. Pulp repair after pulpotomy using different pulp capping agents: a comparative histologic analysis. Pediatr Dent 2011;33(1):14-18

60 Neiva KG, Catalfamo DL, Holliday S, Wallet SM, Pileggi R. Propolis decreases lipopolysaccharide-induced inflammatory mediators in pulp cells and osteoclasts. Dent Traumatol 2014;30(5):362-367

61 Matochek MHM, Tomaz PLS, Oliveira TS, et al. Influence of a propolis-based irrigant solution on gap formation and bond strength of posts bonded to root canal dentin using different resin cements. Dent Mater J In press

62 Pereira TC, da Silva Munhoz Vasconcelos LR, Graeff MSZ, Ribeiro MC, Duarte MAH, de Andrade FB. Intratubular decontamination ability and physicochemical properties of calcium hydroxide pastes. Clin Oral Investig 2019;23(3):1253-1262

63 Gjertsen AW, Stothz KA, Neiva KG, Pileggi R. Effect of propolis on proliferation and apoptosis of periodontal ligament fibroblasts. Oral Surg Oral Med Oral Pathol Oral Radiol Endod 2011;112(6):843-848
64 Santos VR, Pimenta FJ, Aguiar MC, do Carmo MA, Naves MD, Mesquita RA. Oral candidiasis treatment with Brazilian ethanol propolis extract. Phytother Res 2005;19(7):652-654

65 Santos VR, Gomes RT, de Mesquita RA, et al. Efficacy of Brazilian propolis gel for the management of denture stomatitis: a pilot study. Phytother Res 2008;22(11):1544-1547

66 Capistrano HM, de Assis EM, Leal RM, Alvarez-Leite ME, Brener $\mathrm{S}$, Bastos EM. Brazilian green propolis compared to miconazole gel in the treatment of Candida-associated denture stomatitis. Evid Based Complement Alternat Med 2013;2013:947980

67 Bueno-Silva B, Alencar SM, Koo H, et al. Anti-inflammatory and antimicrobial evaluation of neovestitol and vestitol isolated from Brazilian red propolis. J Agric Food Chem 2013;61(19):4546-4550

68 Martins ML, Leite KLF, Pacheco-Filho EF, et al. Efficacy of red propolis hydro-alcoholic extract in controlling Streptococcus mutans biofilm build-up and dental enamel demineralization. Arch Oral Biol 2018;93:56-65

69 das Neves MV, da Silva TM, Lima EO, da Cunha EV, Oliveira EJ. Isoflavone formononetin from red propolis acts as a fungicide against. Candida sp. Braz J Microbiol 2016;47:159-166

70 Bueno-Silva B, Kawamoto D, Ando-Suguimoto ES, Alencar SM, Rosalen PL, Mayer MP. Brazilian red propolis attenuates inflammatory signaling cascade in LPS-activated macrophages. PLoS One 2015;10(12):e0144954

71 Siqueira AB, Rodriguez LR, Santos RK, et al. Antifungal activity of propolis against Candida species isolated from cases of chronic periodontitis. Braz Oral Res 2015;29:29

72 Bezerra AMF, Farias MCAD, Bezerra KK, et al. Red propolis antifungal action on species of Candida of the oral cavity. Int Arch Med 2015;8:1-9

73 Pippi B, Lana AJ, Moraes RC, et al. In vitro evaluation of the acquisition of resistance, antifungal activity and synergism of Brazilian red propolis with antifungal drugs on Candida spp. J Appl Microbiol 2015;118(4):839-850

74 Freires IA, Queiroz VCPP, Furletti VF, et al. Chemical composition and antifungal potential of Brazilian propolis against Candida spp. J Mycol Med 2016;26(2):122-132

75 Ribeiro DR, Alves AV, dos Santos EP, et al. Inhibition of DMBA-induced oral squamous cells carcinoma growth by Brazilian red propolis in rodent model. Basic Clin Pharmacol Toxicol 2015;117(2):85-95

76 Miranda SLF, Damasceno JT, Faveri M, et al. Brazilian red propolis reduces orange-complex periodontopathogens growing in multispecies biofilms. Biofouling 2019;35(3):308-319

77 Alencar SM, Oldoni TL, Castro ML, et al. Chemical composition and biological activity of a new type of Brazilian propolis: red propolis. J Ethnopharmacol 2007;113(2):278-283

78 Chen CL, Parolia A, Pau A, Celerino de Moraes Porto IC. Comparative evaluation of the effectiveness of desensitizing agents in dentine tubule occlusion using scanning electron microscopy. Aust Dent J 2015;60(1):65-72

79 da Silva JLDC, Silva FF, de Souza TFM, et al. Synergic effect of associated green, red and brown Brazilian propolis extract onto. Streptococcus mutans. and. Streptococcus sanguinis. Afr J Pharm Pharmacol 2013;7:2006-2010 